\title{
Taxation of Capital Gains: Principle Versus Practice
}

\author{
NEIL A. STEVENS
}

T HE taxation of capital gains has been a controversial subject ever since the income tax was instituted in 1913. Capital gains have been taxed "preferentially" at lower rates relative to ordinary income since the 1920 s, but the trend in recent years has been to reduce the preference extended to capital gains. Advocates of even further increases for the capital gains tax often contend that a capital gain is no different than ordinary income, such as wage income, and so should not be taxed preferentially. Further, it is often pointed out that those with greater wealth tend to benefit most from the preferential tax treatment of capital gains.

A contrary view has recently gained support in Congress as reductions in capital gains taxes have been included in the tax cut bill recently passed by the Congress. Advocates of a reduction in capital gains taxes often note that the dollar value of some assets has risen sharply in the past decade due to rapid inflation such that the "real" burden of the tax has risen. In view of these rapid increases, some argue that the increases in capital gains taxation have gone too far. They argue that taxation of such gains stifles saving and investment, misallocates resources, and thereby restricts economic growth.

These differing viewpoints about the taxation of capital gains are due, in part, to differing conceptual ideas of what constitutes income. Also, differences arise from diverse assessments of tax considerations such as equity, economic growth, and efficiency. Those desiring to reduce the capital gains tax tend to stress economic efficiency and growth arguments while those desiring to raise such taxes tend to stress equity considerations. The present discussion is intended to give background on the taxation of capital gains and to point out some of the gaps between the way capital gains are currently taxed and the way they would be taxed if recognized principles of taxation were followed.

\section{CAPITAL GAINS TAXATION - THE PRACTICE}

Presently, capital assets are defined in U.S. tax law as all property except that held for sale in the ordinary conduct of business such as business inventories. ${ }^{1}$ Gains (or losses) in the market value of capital assets are recognized under current tax law when they are realized, that is, when the asset is sold or transferred to a new owner, rather than when the market value of the asset actually changes. The current law also distinguishes among capital assets on the basis of the length of time the asset is held. Short-term gains, currently defined as gains on assets held less than one year, are taxed as ordinary income, whereas long-term gains, those on the sale of assets held longer than one year, are taxed at lower rates. ${ }^{2}$ Under current law, long-term capital losses realized by individuals can fully offset long-term capital gains realized in the same period, but only one-half of net long-term losses can be written off against ordinary income, and then, only up to $\$ 3,000$ a year. Losses in excess of these limits can be carried over into subsequent years.

While capital gains are generally not taxed in a number of countries, including Japan and West Germany, ${ }^{3}$ these gains have been taxed in some form in the United States since the institution of income taxation in 1913. Initially, capital gains were taxed as ordinary income, but after a period of rapid inflation during and immediately following World War I, maximum tax rates were reduced on ordinary income as

\footnotetext{
1For further details, see U.S. Master Tax Guide, 1977 (Chicago: Commerce Clearing House, lnc., 1976), pp. 319-25.

2For many years the distinction between short-term and longterm capital gains was six months. Under the 1976 tax legislation, nime months was the dividing point for capital assets sold in 1977 and one year thereafter.

3Richard Goode, The Individual Income Tax (Washington, D.C.: The Brookings Institution, 1976), p. 180.
} 
well as on capital gains. Furthermore, at that time long-term capital gains began to be taxed at preferential rates relative to ordinary income.

From the early 1920 s to the early 1940s, the maximum tax rate on longterm capital gains was changed several times, but it was always lower than rates on ordinary income. From the late 1940 s to the late 1960 s, tax rates on capital gains remained essentially unchanged. During this period, long-term capital gains by individuals were taxed as either ordinary income on one-half of the gain or at a maximum tax rate of 25 percent on the entire gain, whichever yielded the smaller tax.

In recent years, the capital gains tax rate has been raised. The Tax Reform Act of 1969 increased the maximum rate to 35 percent on net long-term gains of $\$ 50,000$ or more; the 25 percent maximum tax rate remained on the first $\$ 50,000$ of net long-term capital gains. Furthermore, a 10 percent minimum tax was levied on several so-called preferential income items of which one item was the excluded one-half of longterm capital gains. ${ }^{4}$ The capital gains tax was increased again in the Tax Reform Act of 1976. The minimum tax was increased to 15 percent on preference income items, and the "basis" on bequeathed property was carried over from the decedent. ${ }^{5}$ Under prior law, the basis of property transferred at death was increased to its current market value, which allowed the avoidance of a capital gains tax on gains during the decedent's lifetime. ${ }^{6}$

The yield from the capital gains taxes has been a relatively small proportion of total income taxes paid to the Federal Government. In 1973 the estimated capital gains tax yield was $\$ 7$ billion, only 4.7 percent of total income taxes collected by the Federal Government. ${ }^{\top}$ In addition, the tax yield from capital gains income has fluctuated substantially from year to year. For example, the capital gains tax is estimated to have yielded $\$ 8.5$ billion in 1968 , but only $\$ 3.4$ billion in 1970.

4The minimum tax pertains to eleven tax preference items. The tax is applied to the sum of these eleven items reduced by either $\$ 10,000$ or one-half of the individual's regular tax liability, whichever is greater.

In many instances, basis is the cost of the asset to the taxpayer. For further details, see U.S. Master Tax Guide, 1977, pp. $309-19$.

Inheritance taxes tended to tax these gains, however, since they were included in the estate of the deceased.

${ }^{7}$ For estimated revenue from the capital gains tax from 1948 to 1973 , see Joseph A. Pechman, Federal Tax Policy, Appendix Table C-13 (Washington, D. C.: The Brookings Institution, 1977), pp. 352-53.

\section{GENERATION OF CAPITAL GAINS}

Capital gains and losses are changes in the market value of capital assets. In order to understand the nature and source of these gains (or losses), this section outlines the basic principles for the valuation of an asset.

In principle, assets are valued for the earnings or services they are expected to provide; that is, the current value of an asset is the value of the expected current and future stream of earnings or imputed services from the asset. However, since a dollar's worth of goods today is worth more than a claim to the same amount of goods in the future, expected income streams cannot simply be added up. Rather they are typically adjusted by some factor which reflects this difference between a dollar received today and a dollar received in the future. This difference is reflected in the rate of interest which can be thought as the inducement to forego current consumption. For example, the capitalization formula for determining the present value of a constant stream of returns (R) over an infinite time span when discounted by some rate of interest (i) is given by the simple formula $\mathrm{P}=\frac{\mathrm{R}}{\mathrm{i}} \cdot{ }^{8}$ If an asset is expected to yield $\$ 100$ a year in perpetuity and is discounted at a 10 percent rate of interest, the present value of the asset is $\$ 1,000$, that is $\left(\frac{\$ 100}{.10}\right)$.

While this formula ignores the complexities of most assets, it is sufficiently general to serve as a tool for classifying the sources of changes in the value of capital assets; namely, those reflecting a change in the expected earnings of the asset and those reflecting a change in the rate at which the earnings stream is capitalized.

An asset changes in value when its expected earnings changes. If the expected income stream increases from $\$ 100$ to $\$ 150$ and is discounted at a 10 percent rate, the value of the asset would be immediately bid

${ }^{8}$ The present value (P) of a constant stream of earnings can be written as $\mathbf{P}=\frac{\mathbf{R}_{0}}{1+i}+\frac{\mathbf{R}_{0}}{(1+\mathbf{i})^{2}}+\ldots+\frac{\mathbf{R}_{0}}{(1+i)^{\mathbf{N}}}$, where $\mathrm{n}_{0}$ is net income, $i$ is the rate of interest and $N$ is the number of periods over which the eamings are expected. This formula can be written in shortened form as simply $P=\sum_{N=1}^{t} \frac{R_{0}}{1(1+i)^{N}}$. When $N$ becomes very large, the formula reduces to $\mathrm{P}=\frac{\mathrm{R}_{\mathrm{e}}}{\mathrm{i}}$. 
up from $\$ 1,000$ to $\$ 1,500$ or $\left(\frac{\$ 150}{.10}\right)$. For purposes of the current discussion, changes in expected earnings are classiffed into those resulting from anticipated changes in relative prices, those resulting from anticipated changes in the general price level, and those resulting from additional investment in the asset.

Changes in relative prices can reflect a whole host of real supply and demand factors, such as changes in technology, population growth, and changes in tastes and preferences of consumers. When changes in supply or demand factors occur such that the expected future earnings of the asset are affected, the value of the asset will immediately be bid up or down.

A second important source of increases in nominal earnings is an increase in the general price level. As the price level is expected to rise, the earnings stream from some assets can also be expected to increase. While the nominal price of these assets will in turn rise over time, the increase in the price, if it reflects the inflation only, does not affect the owner's ability to consume goods and services now or in the future.

A third source of increase in capital value is through additional investment in a capital asset. While the expected income flow from the asset is presumably increased, the asset itself has been changed or added to. Thus, appreciation in asset values reflecting additional investment should be distinguished conceptually from unforeseen revaluations of an income stream from an unaltered asset. However, in practice, observing changes in market values of an asset would not reveal whether the change reflected additional invest ment or an unforeseen revaluation of the income stream.

The value of a given income stream can also change due to interest rate movements. Changes in interest rates may, in turn, reflect revisions in expectations of inflation, changes in the productivity of capital, changes in the evaluation of present and future consumption, or investor attitudes toward risk. If, for example, a perpetual bond pays $\$ 50$ per year, the value of the bond at a 10 percent rate of interest would be $\$ 500$ or $\left(\frac{\$ 50}{.10}\right)$. If the rate of interest should fall to 8 percent because of an anticipated decline in inflation, the value of the bond would increase to $\$ 625$ or $\left(\frac{50}{.08}\right)$.

To summarize, in a world where events are perfectly anticipated, real capital gains of the so-called "pure" type would not occur." While conditions could be changing, these changes would be incorporated into expectations so that no alternation in the earnings stream or discount rate would be a surprise. In actuality, events are not perfectly anticipated so that adjustments in asset values are constantly occurring. Many of these changes, however, involve losses to some and gains to others. Take the earlier example of the perpetual bond. The owner of the bond gained when interest rates declined; however, the issuer of the bond loses to a like extent since the "real" value of the coupon has increased.

\section{A PRINCIPLE FOR TAXATION OF CAPITAL GAINS}

Whether capital gains should be taxed in principle depends on the measure of income chosen. For tax ation purposes, two primary definitions have been offered. One view of income, as promoted by Irving Fisher and others, defines income simply as services actually consumed from wealth; whereas, services received from wealth but not consumed (saving) are not regarded as income. ${ }^{10}$ Essentially, Fisher defined income as what is normally regarded as consumption. A second view of income promoted by Henry Simons, among others, defined income as "the algebraic sum of (1) the market value of rights exercised in consumption and (2) the change in the value of the store of property rights between the beginning and end of the period in question." 11 This definition is generally referred to as the accretion principle which means simply that income equals the increase in the individual's net worth plus consumption during the period.

These two measures of income would appear to imply substantially different taxes, yet they are not as dissimilar as they at first may seem. The primary difference between the two views of income is one of timing in recognition of purchasing power. Fisher's definition recognizes income when it is spent, whereas the accretion principle recognizes income when it is

\footnotetext{
Pure capital gains are often defined as unexpected rises in the value of an asset as distinguished from expected increases in the market value of an asset resulting, for example, from increased investment in an asset. For a discussion, see Lawrence H. Seltzer, The Natuje and Tax Treatment of Capital Gains and Losses (New York: National Bureau of Economic Research, 1951), pp. 53-54.

10Irving Fisher, The Nature of Capital and Income, original edition in 1906, reprinted as a series title in Reprints of Economic Classics (New York: August M. Kelley, 1965).

${ }^{11}$ Henry C. Simons, Personal Income Taxation: The Definition of Incothe as a problem of Fiscal Policty (Chicago: University of Chicago Press, 1938), p. 50.
} 
earmed. If savings are eventually spent over a person's lifetime (including bequests), the present value of the tax liabilities would be equivalent under the two definitions. ${ }^{12}$

While these views of inoome are similar, the accretion view emphasizes that receipts which are saved confer the same benefits, in terms of purchasing power or ability to pay, as receipts which are used to consume goods and services. Given currently prevailing social values, the accretion principle has become the dominant measure of income for tax purposes.

\section{DISCREPANCIES BETWEEN PRINCIPLE AND PRACTICE}

While the accretion principle provides the standard measure of income for taxation purposes in this country, a large gap exists between the way income, and in particular capital gains, are taxed in practice and the way they wotld be taxed according to this principle. These deviations are sometimes due to different conceptual interpretations of the accretion principle, and sometimes they reflect administrative problems.

\section{Double Taxation}

While in principle an income stream should be taxed only once, taxation of capital gains on market income-bearing assets raises conceptual problems of whether double taxation occurs when both the current earnings and the change in wealth associated with the income stream are taxed. Using again the simple valuation formula $P=R / t$, suppose a tax of $t$ percent is applied to the stream of returns, $R$. The valuation formula then becomes $P=\frac{R(1-t)}{i}$, that is, the value of the asset is reduced by t percent with the imposition of a tax on the earnings from the asset. If, for example, a 50 percent proportional tax is levied on a $\$ 100$ stream of income, the value of the asset is low-

12The present values of the tax liabilities under the two tax sehemes are equal if the yield on savings is the same as the discount rate on future income. Under a consumption tax of $t$ percent and a propensity to consume of $c$ percent, the present value ( $P$ ) of the tax on a receipt (R) is given by the formula: $\mathrm{P}=\mathrm{tcR}+\frac{\mathrm{t}(1-\mathrm{c}) \mathrm{R}(1+\mathrm{g})^{\mathrm{N}}}{(1+\mathrm{i})^{\mathrm{N}}}$, where $\mathrm{g}$ is the rate of interest obtained on savings, $i$ is the rate at which future income is discounted, and $\mathrm{N}$ is the period in which the savings is consumed. If $g$ equals $i$, the second term becomes $t(1-c) R$, so that the present value of the tax is tcR + $t(1-c)$ R or simply $t R$. Under an income tax of $t$ percent, a receipt is taxed only in the period received so the present value of the tax is simply $t R$. Thus, the present value of the tax liabilities are equivalent under such circumstances. ered from $\$ 1,000$ or $\left(\frac{\$ 100}{.10}\right)$ to only $\$ 500$ or $\left[\frac{\$ 100(1-.5)}{.10}\right]$. The tax on income is reflected in an implicit tax on the value of the asset.

If the income stream is expected to rise to $\$ 150$ due to a favorable change in the market valuation of the services of the asset (or the real interest rate declines to 6.67 percent), the after-tax value of the asset will be bid up to only $\$ 750$. In the absence of the income tax, the value of the income stream or the asset value would have risen $\$ 500$ (from $\$ 1,000$ to $\$ 1,500$ ), due to the expected $\$ 50$ increase in income. However, since the income tax reduces this gain in income to $\$ 250$, the asset rises in value by only $\$ 250$. Thus, an implicit tax of $\$ 250$ on capital gains is paid by means of the ordinary income tax on the extra income. Thus, if an additional tax is imposed on the capital gain associated with a rise in expected future earnings, the income from the asset is being taxed twice, once on the increased stream of income as it occurs and once on the anticipation of the increased stream of income.

The above analysis implies that the capital gains tax should be completely removed from those assets which generate income streams that are fully taxed by the income tax on ordinary income. In principle, a capital gains tax would remain on the appreciation of an asset, where that appreciation in value is due to a nontaxed increase in the income derived from it. The most notable example is owner-occupied housing which yields an imputed income equal to that achievable if the house were rented. A capital gains tax would not capture the entire income stream from such an asset, but at least would capture the increases in the income stream.

Corporate Income and Triple Taxation - Under current tax laws, dividends paid by corporations to stockholders are subject to three taxes - first, the cor porate income tax, second, the ordinary income tax on dividends, and third, the capital gains tax. To illustrate this point, suppose a corporation, which pays out all of its earnings in dividends to its shareholders, has an unexpected increase in its earnings per share from $\$ 10$ to $\$ 20$ per year. In the absence of a tax on this income, the value of a share of stock would have appreciated $\$ 100$ or $\left(\frac{\$ 20}{.10}-\frac{\$ 10}{.10}\right)$. If, however, there is a 50 percent tax on corporate income and another 25 percent tax, at the margin, on dividend income, the after-tax value of the stock will in- 
crease only $\$ 37.50$ or $\left[\frac{\$ 20(.5)(.75)}{.10}-\frac{\$ 10(.5)(.75)}{.10}\right]$

As a result of these two taxes, the before-tax increase in the expected income stream is implicitly taxed $\$ 62.50 ; \$ 50$ by the tax on corporate income, and $\$ 12.50$ by the individual tax on dividends. If, in addition, a capital gains tax is imposed on the $\$ 37.50$ gain realized by the sale of a share of stock, the same increase in corporate earnings would be taxed a third time.

Some analysts advocate the taxation of capital gains since corporations can choose to retain their earnings and reinvest them in order to increase future income (and create a capital gain by increasing the real capital claim represented by a given share of stock). Retention of corporate earnings allows the taxpayer to defer taxes into the future, thus giving preferential treatment to these earnings relative to dividends paid to stockholders.

The taxation of capital gains, however, is a second best solution. Since the problem arises because earned corporate income can be diverted from realized in come (dividends) to retained earnings, the solution is to remove the possibility of avoiding income taxation through retained earnings. The generally recognized means of accomplishing this is to eliminate the corporate income tax and fully apportion all the earnings of the corporation among the stockholders. Under this solution corporation earnings (whether retained or not) would be taxed only once on the individual stockholder's income tax return. ${ }^{13}$ Since corporate income would be fully taxed as ordinary income, no additional tax would need to be imposed on increases in the value of corporate stock.

Administrative Problems - Conceptually, in order to avoid double taxation, a capital gains tax should be applied only to those assets whose income streams are not fully subject to ordinary income taxation. Yet, the application of this principle for capital gains taxation presents major administrative problems. The difficulty arises because only the market value of an asset can be observed; thus, separating that portion of the asset appreciation which represents income which has escaped ordinary taxation is very difficult. This type of problem even arises in cases where the income stream from the asset is not taxed at all, such as owner-occupied housing, because

\footnotetext{
13Proposals to eliminate multiple taxation of corporate income through integration of the corporate and individual income taxes have been often proposed. For example, see George $F$ Break and Joseph A. Pechnan, Federal Tax Reform: The Impossible Dream? (Washiugton, D.C.; The Brookings Institution, 1975), pp. 90-104.
}

observed market values also incorporate purely inflation gains.

\section{Inflationary Gains}

The most questionable aspect of current capital gains taxation regards those gains in asset values which simply reflect the general rise in prices. Since these gains do not represent real increases in the command over goods and services, such gains should not be included in the income tax base. ${ }^{14}$

The rapid inflation of the past ten years has brought about large increases in asset values, as the consumer price index has risen about 80 percent. Thus, an asset which cost $\$ 100,000$ ten years ago would have had to appreciate approximately $\$ 80,000$ in order to have maintained its consumer purchasing power of ten years ago.

While there is widespread agreement that gains in nominal value as a result of inflation should not be taxed, there are practical, as well as conceptual, diffculties in separating real gains from the price increase caused by inflation. One method of adjustment could be to change the basis (or cost) of the asset by an appropriate factor based upon some price index. For depreciable assets, a method of cost accounting based upon the replacement cost rather than the historical cost of an asset would help alleviate the inflation bias.

\section{Bunching of Gains}

In principle, capital gains would be taxed as they accrue. Largely for the administrative reason that assets would need to be revalued each year, capital gains are presently taxed only when realized, that is, when the asset is sold. Thus, unrealized gains can accrue over a number of years. Taxing such gains when they are realized as ordinary income can result in a greater tax liability because of the progressive income tax structure than if the gain had been taxed as it accrued over time. ${ }^{15}$

This problem, however, could be alleviated by taxing capital gains as they accrue or by using an income averaging technique. ${ }^{16}$ There is general agreethe effects of inflation on income taxation are not mique to Tatom and James E. Turley, "Inflation and Taxes: Disincentives for Capital Formation," this Review (January 1978), pp. 2-8, and Nancy Jianakoplos, "Paying More Taxes and Affording It Less," this Review (July 1975), pp. 9-13.

15Tending to offset this loss is the gain associated with the deferral of capital gains taxes until the preceeds from the sale of an asset are realized.

16 Obviously a reduction in the progressivity of the income tax structure or a simple proportional income tax would also eliminate these problems. 
ment that practical considerations involved in revaluating capital assets each year precludes the taxing of gains as they occur. If capital gains are to be taxed at ordinary rates, however, there is considerable merit in using averaging techniques to overcome the bunching problem.

\section{Economic Efficiency and Growth Considerations}

Arguments are frequently made that taxation of capital gains discriminates against saving, so that a decrease in the rate of taxation of capital gains would stimulate saving, investment, and economic growth. In principle, the argument that the taxation of capital gains reduces saving is really a part of a more general argument that an income tax tends to discourage saving relative to consumption. ${ }^{17}$ In practice, however, several features of the current treatment of capital gains further discriminates against saving and in some cases creates inefficiencies.

The current asymmetrical treatment of capital losses reduces the incentive to save and tends to inhibit risk-taking ventures. As indicated earlier, under current law long-term capital losses can be offset against long-term capital gains in full, but only onehalf of net long-term capital losses, up to a maximum of $\$ 3,000$, can be written off in any one year against ordinary income. Such treatment of capital gains and losses increases Government revenue from what it would be if losses and gains were treated equally. Therefore, savings are reduced from what they otherwise would be. Furthermore, because the risks of losses are borne more fully by the businessmen, launching new ventures, which by their nature are quite risky, is inhibited by the unequal treatment of gains and losses.

The fact that capital gains are taxed when realized rather than when they accrue results in economic inefficiency due to the resulting "lock-in" effect. This effect occurs because as gains accrue and a potential tax liability accumulates, investors become reluctant to shift assets in their portfolios. When making

\footnotetext{
13 In principle, this argument is true of an income tax which includes both saving and consumption. An income tax based on a proper implementation of the accretion principle is not neitral with respect to current and future consumption. A proportional tax on both labor income and capital income tends to discourage saving relative to consumption. In addition, if the tax structure is progressive rather than proportional and individuals tend to save a higher proportion of their income as their incomes nise, saving will be even further reduced relative to consumption. For detajs of these arguments, see Richard A. Musgrave, The Theory of Public Enonce (New York: MeGraw-Hill Book Company, Inc, $1959)$.
}

the decision to shift between assets where substantial capital gains have been accumulated, high enough yields must be anticipated to compensate for the capital taxed away. The additional rate of return which the new assets must be expected to yield increases with the size of the gain on the old asset and the investor's marginal tax bracket.

This lock-in effect influences economic efficiency in several ways. The productivity of an asset may diminish when it is dependent on the owner and that owner no longer employs the asset in its most efficient use. The lock-in effect may also reduce the well being of households by forcing them to hold assets they would otherwise rather not hold. For example, an owner of risky stocks during high income years may find that during his retirement years he would prefer less risky dividend-paying stocks. Large capital gains taxes would tend to preclude the owner from changing his portfolio in the desired way.

\section{CURRENT CAPITAL GAINS TAX PROPOSALS}

Several proposals have been offered in the present Congress to reduce the tax on capital gains. Last August the House of Representatives passed a tax cut bill which included the lowering of the maximum rate on capital gains from 49 to 35 percent by removing the minimum tax on the excluded portion of capital gains income, but a new 10 percent alternative minimum tax was imposed if this tax exceeded an individual taxpayer's regular tax liability. Two additional features of the House-passed tax cut bill which affected capital gains were a provision for indexing of capital gains for inflation starting in 1980 and a provision that gave homeowners a once-in-a-lifetime opportunity to realize up to $\$ 100,000$ in gains from the sale of their home tax-free without regard to whether another home was purchased. The tax cut bill recently passed by the Senate raised the exclusion for longterm capital gains from 50 to 70 percent and lowered capital gains taxes on homes by excluding gains on homes priced under $\$ 100,000$ when sold by individuals 55 years of age or older.

The tax bill sent to the President for his signature represents a compromise, worked out in a conference committee, between these two bills. In the final bill the exclusion of long-term capital gains from regular income taxation for individuals is increased from the current 50 percent to 60 percent. A new alternative minimum tax is included in the final bill which would be paid on the excluded portion of capital 
gains only if it exceeds regular taxes plus the existing minimum tax which is now altered to include a list of only eight preference items. The maximum marginal bracket for the new alternative minimum tax is 25 percent for amounts exceeding $\$ 80,000$. In addition, the bill provides that homeowners, 55 years and older, can exclude a gain of up to $\$ 100,000$ on a sale of their home.

The provisions of the current tax bill sent to the President do little in the way of fundamental reform under the accretion principle. Lowering the capital gains tax rate, however, is in the right direction for assets which bear explicit market incomes. Such a reduction also will help increase saving and make investment more attractive. Yet substantial double taxation of some types of assets will remain along with a number of adverse features of the present tax law concerning capital gains.

Ironically, the proposed capital gains tax relief on owner-occupied homes has been retained in the final tax bill sent to the President, despite the fact that taxation of these gains (to the extent they are real gains) is the most justifiable on economic grounds of all capital gains taxes. In the current income tax base, the imputed rental value of owner-occupied dwellings are not included, although in principle it is income. Thus, as noted earlier, the taxing of the capital gains on such housing is one way to capture part of this implicit income. If the tax cut bill is signed by the President and becomes law, these implicit rents will not be taxed until they rise by a very large amount. Since owner-occupied housing will be treated differently than other assets, there will be an even stronger incentive to invest in homes rather than in other assets. Thus, investors will be encouraged to hold more of the nation's capital in the form of housing relative to other investment goods.

\section{CONCLUSION}

The controversy over the appropriate taxation of capital gains income has been rekindled and the recent Congressional tax cut bill calls for the reduction of taxes on such gains. With rapid inflation increasing real tax burdens on capital gains and with growing national concern about lagging investment and productivity growth, it becomes understandable why proposals to reduce capital gains taxation have gained so much support in Congress.

The taxation of capital gains, as practiced in the United States, is quite different from that implied by the accretion principle. Equity considerations alone would result in capital gains income being taxed only on assets where the income streams are not subject to ordinary income taxation. Thus, capital gains should be removed for assets which yield market income. As demonstrated earlier, the market value of such assets are after-tax values, so that a tax has already been imposed on assets which yield market incomes. Furthermore, on those assets where the capital gains tax remains, the accretion principle implies that only real gains should be taxed and that losses should be treated equally with gains.

The discrepancy between the practice of capital gains taxation in this country and the accretion principle for taxing such gains also adversely affects economic growth and efficiency. Double taxation of some assets, taxation of inflationary gains, and treating losses differently than gains tend to reduce saving, investment, and thus economic growth. Tailoring the capital gains tax after the accretion principle would not only improve the equity of the tax system, but at the same time would encourage economic growth and efficiency.

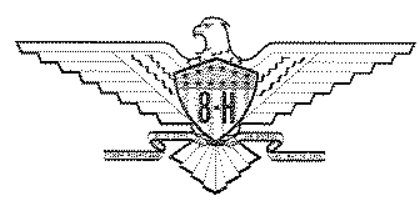

